\title{
Analysis of life quality and prevalence of cognitive impairment, anxiety, and depressive symptoms in older adults
}

\author{
Análise da qualidade de vida e prevalência \\ de declínio cognitivo, ansiedade e \\ sintomas depressivos em idosos
}

\author{
Michele Marinho da SILVEIRA \\ Mirna Wetters PORTUGUEZ ${ }^{2}$
}

\begin{abstract}
The development of anxiety, depressive symptoms, and a decrease in cognitive performance can affect older adults' quality of life. The objective of this cross-sectional study was to analyze quality of life and determine the prevalence of cognitive impairment, anxiety, and depression symptoms in senior center participants. A total of 120 older adults living in the city of Passo Fundo, RS, Brazil, participated in this study. The convenience sampling technique was used. All participants answered questions relative to socio-demographic variables, quality of life (World Health Organization Quality of Life-Bref), cognitive performance (Addenbrooke' Cognitive Examination), and emotional state (Geriatric Depression Scale and Beck Anxiety Inventory). The prevalence of anxiety, depressive symptoms, and cognitive impairment were low indicating satisfactory quality of life of the older adults investigated.
\end{abstract}

Keywords: Aging; Cognition; Depression; Life change events; Stress, psychological.

\section{Resumo}

O desenvolvimento de ansiedade, de sintomas depressivos e a diminuição do desempenho cognitivo podem alterar a qualidade de vida do idoso. O objetivo deste estudo transversal foi analisar a qualidade de vida e verificar a prevalência de declínio cognitivo, ansiedade e sintomas depressivos de participantes de grupos de convivência. O estudo teve a participação de 120 idosos do município de Passo Fundo, RS. Utilizou-se o método amostral de conveniência. Todos os participantes responderam sobre condições sociodemográficas, qualidade de vida (World Health Organization Quality of Life Group-Bref), desempenho cognitivo (Exame Cognitivo de Addenbrooke) e estado emocional (Escala de Depressão Geriátrica e Inventário de Ansiedade de Beck). A prevalência de ansiedade, sintomas depressivos e declínio cognitivo foram baixos, repercutindo positivamente na qualidade de vida dos idosos, que se mostrou boa e satisfatória.

Palavras-chave: Envelhecimento; Cognição; Depressão; Acontecimentos que mudam a vida; Estresse psicológico.

$\nabla \nabla \nabla$

1 Faculdade Meridional, Escola de Saúde, Curso de Psicologia. R. Senador Pinheiro, 304, Bairro Rodrigues, 99070-220, Passo Fundo, RS, Brasil. Correspondência para/Correspondence to: M.M. SILVEIRA. E-mail: <michele.msilveira@gmail.com>.

2 Pontifícia Universidade Católica do Rio Grande do Sul, Faculdade de Medicina, Programa de Pós-Graduação em Gerontologia Biomédica. Porto Alegre, RS, Brasil. 
Aging is a natural process that causes changes in the body structure and function, reducing vitality and triggering the onset of agerelated diseases (Lopes, Nascimento, Esteves, Terroso, \& Argimon, 2013). Among the many disorders affecting the elderly, depression, anxiety, and cognitive impairment deserve special attention since they have high prevalence and a negative impact on the Quality of Life (QoL) in patients with dementia (Hamdan \& Corrêa, 2009).

The onset and progression of cognitive impairment varies depending on educational, health, and personality factors, as well as on the overall intellectual level and mental capacities of the individual (Guedes, Barbosa, \& Magalhães, 2013). Older adults with cognitive impairment and experiencing difficulties in performing activities of daily living are at risk of losing independence, which leads to feelings of uselessness, lowers their quality of life, and worsens their emotional state (Tavares \& Dias, 2012).

It has been shown that older adults with depressive symptoms and severe anxiety symptoms have cognitive deficit or impairment (García-Pena et al., 2008; Yen, Rebok, Gallo, Jones, \& Tennstedt, 2011). Anxiety and depressive disorders are common among older adults, and are considered as the main causes of emotional distress and reduced quality of life (Minghelli, Tomé, Nunes, Neves, \& Simões, 2013). It is known that elderly people with mild cognitive impairment and depression are at increased risk of developing dementia than those who have one or the other disorder (Scoralick, Pinheiro, Silva, \& Cunha, 2011).

Brazilian epidemiological studies with older adults have shown that the prevalence of depressive symptoms varies between 19 and 34\% in different regions of the country (Batistoni, Neri, \& Cupertino, 2010; Benedetti, Borges, Petroski, \& Gonçalves, 2008; Hoffmann, Ribeiro, Farnese, \& Lima, 2010; Lima, Silva, \& Ramos, 2009). The high prevalence of depression is an important public health problem, which deserves attention from health professionals and health service managers.

On the other hand, it has been reported that active older adults who participate in senior centers show good or satisfactory quality of life (Serbim \& Figueiredo, 2011; Silva, Carvalho, Lima, \& Rodrigues, 2011). Such quality of life is a common need of the elderly, and is described in terms of functional capacity, independence, and ability to engage in everyday life activities (Vitorino, Paskulin, \& Vianna, 2013). According to the World Health Organization (1995), quality of life is defined as an individual's perception of his/her position in life in the context of the culture and value systems in which he/she lives, and in relation to his/her goals, expectations, standards and concerns. This is a broad-ranging and complex concept encompassing physical health, psychological state, level of independence, social relationships, personal beliefs, and relationship with features of the environment.

Therefore, the present study aimed to analyze quality of life and determine the prevalence of cognitive impairment, anxiety, and depressive symptoms in older adults participating in senior centers.

\section{Method}

\section{Participants}

This descriptive cross-sectional study was carried out in a convenience sample of 120 participants from two senior centers in the city of Passo Fundo, RS, Centro Regional de Estudos e Atividades da Terceira Idade (Regional Center of Studies and Activities of the Third Age) and Departamento de Atenção ao Idoso (Department for Elderly Care). All participants were elderly of both genders, aged 60 years or older, had an active lifestyle, and lived in the community.

The participants were selected using the convenience sampling technique in these two senior centers, where they were engaged in cognitive, physical, and social activities. The older adults were selected according to the following inclusion criteria: they had to be participants at one of the two senior centers and had to be at least 60 years of age. Accordingly, of the 148 individuals interviewed, 28 were excluded. 


\section{Instruments}

The following instruments were used: a Socio-demographic and Health Questionnaire, Geriatric Depression Scale (GDS-15), Beck Anxiety Inventory (BAI), World Health Organization Quality of Life - BREF (WHOQOL-BREF), and Addenbrooke's Cognitive Examination - Revised (ACE-R). The administration of these instruments to each participant required approximately $11 / 2$ hours. Data was collected individually in a quiet room at the senior centers.

Socio-Demographic and Health Questionnaire. The questionnaire included gender, age, level of education, income, marital status, and perceived health and memory status. It was prepared by the authors to determine the participants' profile.

Geriatric Depression Scale (Yesavage et al., 1983). Is an instrument used to assess depressive symptoms and screen for depression. It is a series of 15 yes/no questions; 0 or 1 point is scored for each response. A total score greater than five points is suggestive of depression.

Beck Anxiety Inventory (Cunha, 2001). Is an instrument to measure the severity and intensity of anxiety symptoms. It is composed of 21 items scored 0-4 that rate symptoms as absent, mild, moderate, and severe. A total score greater than 20 points is suggestive of Anxiety symptoms.

World Health Organization Quality of Life - BREF this is instrument used to assesses four domains of quality of life (physical, psychological, social relationships, and environment), including a score relating to overall quality of life. It is composed of 26 items scored 1-5. There are no cut-off points; the higher the score (0-100), the better the quality of life (Fleck et al., 2000).

Addenbrooke Cognitive Examination, a brief cognitive screening test that assesses five neurocognitive domains: attention/orientation (18 points), memory (26 points), verbal fluency (14 points), language (26 points), and visuospatial abilities (16 points). Cut-off points are calculated based on the level of education: $\geq 50$ points for illiterate, $\geq 60$ points for $1-4$ four years of schooling, $\geq 70$ points for $5-8$ years of schooling, $\geq 80$ points for more than 9 years of schooling. Total score is 100. High scores are suggestive of better cognitive function (Carvalho \& Caramelli, 2007).

\section{Procedures}

This study approved by the Scientific Committee of the Institute of Geriatrics and Gerontology of the Pontificia Universidade Católica do Rio Grande do Sul (PUCRS, Pontifical Catholic University of Rio Grande do Sul) and by the Research Ethics Committee of the PUCRS, Porto Alegre, RS, Brazil (Protocol n² 241.858, Process $\left.n^{\circ} 12546413.2 .0000 .5336\right)$. After getting the approval, the senior centers were contacted and the participants were selected.

All individuals who agreed to participate were individually interviewed, signed the Informed Consent form, and answered the sociodemographic and health questionnaire and questions relative to the cognitive performance functions (ACE-R), depressive symptoms (GDS-15), anxiety symptoms (BAI), and perception of quality of life (WHOQOL-BREF).

In the data analysis, numerical variables were expressed as mean \pm standard deviation or median (25th and 75th percentiles), according to the distribution, i.e., if it was normally or not normally distributed. The qualitative variables were described as absolute and relative frequencies. The correlation between the total score of the ACE-R, BAI, GDS-15, and the domains of quality of life and overall QoL (WHOQOL-BREF) were determined using Pearson's correlation coefficient; the correlation was considered statistically significant when $p<0.05$. Data were stored using Microsoft Excel 2010 for Windows and were analyzed using the Statistical Package for Social Sciences (SPSS) for Windows, version 17.0.

\section{Results}

Table 1 shows the socio-demographic profile of the sample. The mean age of participants was 
Table 1

Socio-demographic and health characteristics of the sample $(n=120)$

\begin{tabular}{|c|c|c|}
\hline Variables & $\mathrm{N}$ & $\%$ \\
\hline \multicolumn{3}{|l|}{ Sex } \\
\hline Female & 94 & 78.3 \\
\hline Male & 26 & 21.7 \\
\hline \multicolumn{3}{|l|}{ Age } \\
\hline $60-69$ years & 90 & 75.0 \\
\hline 70-79 years & 26 & 21.7 \\
\hline $80-89$ years & 4 & 3.3 \\
\hline \multicolumn{3}{|l|}{ Marital status } \\
\hline Single & 10 & 8.3 \\
\hline Married & 57 & 47.5 \\
\hline Separated/Divorced & 15 & 12.5 \\
\hline Widowed & 38 & 31.7 \\
\hline \multicolumn{3}{|l|}{ Level of education } \\
\hline 4 years of schooling & 31 & 25.8 \\
\hline 8 years of schooling & 16 & 13.3 \\
\hline 11 years of schooling & 40 & 33.3 \\
\hline More than 12 years of schooling & 33 & 27.5 \\
\hline \multicolumn{3}{|l|}{ Monthly income } \\
\hline $1-2$ times the minimum wage & 68 & 56.7 \\
\hline 3-4 times the minimum wage & 31 & 25.8 \\
\hline More than 5 times the minimum wage & 21 & 17.5 \\
\hline \multicolumn{3}{|l|}{ Perception of memory } \\
\hline Excellent/good & 51 & 42.5 \\
\hline Fair/poor & 69 & 57.5 \\
\hline \multicolumn{3}{|l|}{ Are forgetful } \\
\hline Yes & 101 & 84.2 \\
\hline No & 19 & 15.8 \\
\hline \multicolumn{3}{|l|}{ Perception of health } \\
\hline Excellent/good & 75 & 62.5 \\
\hline Fair/poor & 45 & 37.5 \\
\hline
\end{tabular}

Note: Absolute frequency values (relative frequency).

$66.61 \pm 5.638$ years; $78.3 \%$ of the participants were female and $21.7 \%$ were male. Most of them (75\%) were aged between 60 and 69 years; 33.3\% had 11 years of schooling (completed high school - Brazil). Most participants (57.5\%) perceived their memory as fair/poor, and $84.2 \%$ reported forgetfulness. However, $62.5 \%$ of the participants perceived their health as excellent/good for.

Table 2 shows the analysis of quality of life. It was found that the studied population had a good and satisfactory quality of life (total score ranging from 0-100); the higher the score, the better the quality of life. The overall score was $70.65 \pm 14.92$

264 points.
Table 2

Quality of life - World Health Organization Quality of Life - BREF $(n=120)$

\begin{tabular}{lcc}
\hline Domain & Mean & Standard Deviation \\
\hline Physical & 72.38 & 15.35 \\
Psychological & 70.90 & 12.36 \\
Social Relationships & 70.55 & 17.58 \\
Environment & 68.80 & 14.40 \\
Overall & 70.65 & 14.92 \\
\hline
\end{tabular}

Ninety participants (75\%) did not have signs or symptoms of cognitive impairment, and 30 (25\%) showed cognitive impairment. Table 3 shows the emotional state (anxiety and depressive symptoms) of the participants. It was observed low prevalence of depressive symptoms and low levels of anxiety. Only $10(8.33 \%)$ participants showed anxious symptoms, and $19(15.83 \%)$ had depressive symptoms.

Table 4 shows the relationships between the domains of quality of life, depression, anxiety, and cognitive performance. The domains of QoL scores were significantly correlated $(p<0.05)$ with the scores of the following scales: anxiety, depression, and cognitive impairment. However, no correlation was found between cognitive impairment and depression.

\section{Discussion}

It was found that the population studied showed good quality of life, low prevalence of cognitive impairment, and low levels of anxiety and depressive symptoms. In accordance with the literature (Yassuda \& Silva, 2010), the results obtained suggest that participation in senior centers has a positive effect on cognition, emotional state, and life satisfaction. In contrast, some studies on older adults residing in long-term care facilities found that their quality of life is not satisfactory (Freitas \& Scheicher, 2010; Oliveira, Gomes, \& Paiva, 2011) and many showed cognitive impairment (Rocha, Klein, \& Pasqualotti, 2014) and depressive symptoms (Galhardo, Mariosa, \& Takata, 2010).

Some studies have shown that elderly people with chronic diseases undergoing hemodialysis and 
Table 3

Emotional state $(n=120)$

\begin{tabular}{lcccc}
\hline Variable & Median & 25th $p$ - 75th $p$ & Mean & Standard Deviation \\
\hline Beck Anxiety Inventory & 4 & $1-11$ & 7.21 & 8.77 \\
Geriatric Depression Scale - 15 & 3 & $2-5$ & 3.53 & 2.32 \\
\hline
\end{tabular}

Table 4

Correlation between the scores of the scales and the domains of QoL scores $(n=120)$

\begin{tabular}{lccccccc}
\hline Domains of QoL scale & BAl & GDS-15 & ACE-R & PD & PsycD & SRD & ED \\
\hline BAI & 1 & $-0.384^{* *}$ & $-0.202^{*}$ & $-0.354^{* *}$ & $-0.346^{* *}$ & $-0.205^{*}$ & $-0.380^{* *}$ \\
GDS-15 & $-0.384^{* *}$ & 1 & -0.021 & $-0.411^{* *}$ & $-0.547^{* *}$ & $-0.409^{* *}$ & $-0.333^{* *}$ \\
ACE-R & $-0.202^{*}$ & -0.021 & 1 & $0.549^{* *}$ & $0.494^{* *}$ & $0.546^{* *}$ & $0.674^{* *}$ \\
PD & $-0.354^{* *}$ & $-0.411^{* *}$ & $0.549^{* *}$ & 1 & $0.652^{* *}$ & $0.380^{* *}$ & $0.566^{* *}$ \\
PsycD & $-0.346^{* *}$ & $-0.547^{* *}$ & $0.494^{* *}$ & $0.652^{* *}$ & 1 & $0.577^{* *}$ & $0.652^{* *}$ \\
SRD & $-0.205^{*}$ & $-0.409^{* *}$ & $0.546^{* *}$ & $0.380^{* *}$ & $0.577^{* *}$ & 1 & $0.543^{* *}$ \\
ED & $-0.380^{* *}$ & $-0.333^{* *}$ & $0.674^{* *}$ & $0.566^{* *}$ & $0.652^{* *}$ & $0.543^{* *}$ & 1 \\
\hline
\end{tabular}

Note: ${ }^{*}$ Correlation is statistically significant at the 0.05 level; ${ }^{* *}$ Correlation is statistically significant at the 0.01 level.

BAl: Beck Anxiety Inventory; GDS-15: Geriatric Depression Scale; ACE-R: Addenbrooke's Cognitive Examination; QoL: Quality of Life. Domains of the QoL scale: PD (Physical Domain), PsycD (Psychological Domain), SRD (Social Relationship Domain), and ED (Environment Domain).

those who had suffered a stroke had low scores of quality of life, which was considered unsatisfactory (Rangel, Belasco, \& Diccini, 2013; Takemoto, Okubo, Bedendo, \& Carreira, 2011), and depressive symptoms (Braga et al., 2011). These findings are very different from those of the present study, which showed a good and satisfactory quality of life and low prevalence of depressive symptoms.

Moreover, it was found in the present study that although some participants reported forgetful and perceived their memory fair and poor, they perceived their health as excellent or good, corroborating with the studies by Benedetti, Mazo, and Borges (2012) and Almeida, Madeira, Arantes, and Alencar (2010), who reported that older adults participating in senior centers also showed good perception of health.

Some researchers found a positive relationship between cognitive function and quality of life (Beckert, Irigaray, \& Trentini, 2012) and others argue that the more severe the cognitive impairment, the lower the quality of life (Leite et al., 2012a; Leite, Winck, Hildebrandt, Kirchner, \& Silva, 2012b). Similarly, the findings of Winocur et al. (2007) support the hypothesis that quality of life contributes to successful aging, more specifically, it contributes to preserve cognitive function.

Another plausible explanation for the positive perception of quality of life would be that the participants create new social networks as a result of their contact with other older adults in senior centers. It has been shown that the participation in senior centers can improve the quality of life (Erbolato, 2004; Serbim \& Figueredo, 2011), reduce social isolation and depression (Andrade et al., 2014; Koch et al., 2013), and anxiety (Andrade, Mendonça, Lima, Alfenas, \& Bonolo, 2012). Some researchers have suggested that social interaction offers older adults many benefits by improving cognitive performance and enhancing life satisfaction (Yassuda \& Silva, 2010).

It is known that most social network participants are able to make their own decisions and have a somewhat satisfactory quality of life. It is important to highlight the fact that all older adults in the present study participate in senior centers; the emancipatory practices adopted in this type of center influence the quality of life of their participants. Social networks are effective in the improving and/or maintaining quality of life of older 
people, providing enjoyable communication experiences, confidence, leisure, sense of security, and support to deal with critical situations (Silveira, 2012).

Relationships between anxiety and depression corroborate with findings of other researchers (Minghelli et al., 2013). Unlike other studies (Brigola et al., 2015; Silva et al., 2014), the present study showed no relationship between depression and cognitive state, which is in agreement with the results reported by Paulo and Yassuda (2010).

Relationships between quality of life, anxiety, depression, and cognition have also been reported in other studies (Antunes, Stella, Santos, Bueno, \& Mello, 2005; Silva et al., 2014). Older adults with late-onset depression showed weaker performance on tasks involving information processing speed and executive functions (Steibel \& Almeida, 2010), demonstrating that there is a relationship between depression and cognitive aspects.

Chaves et al. (2014) investigated 287 older adults and found a high satisfaction with quality of life although $83 \%$ of the participants had minor depression. It has been shown that physically active older adults are less likely to have cognitive impairment, anxiety symptoms, and depression (Leite et al., 2012a).

According to Hultsch, Hertzog, Small, and Dixon (1999), engaging in intellectual activities is a possible protective factor against cognitive impairment in elderly people. These authors offer an alternative hypothesis suggesting that highability individuals lead intellectually active lives until cognitive impairment in old age limits their activities. Argimon, Stein, Xavier, and Trentini (2004) argue that the higher the degree of participation of older adults in leisure activities, the higher their cognitive performance. Leisure and ability to perform physical and mental activities lead to better quality of life. Level of education and more leisure options are protective factors against the decline in cognitive abilities in older people.

Based on the findings of the present study, it can be concluded that cognitively stimulating lifestyles, with challenging group activities, such as participating in senior centers in pursuit of an active aging with physical activities and leisure opportunities, appears to be a predictor of good outcomes in terms of quality of life and emotional and cognitive states in older adults.

\section{Contributors}

M.M. SILVEIRA worked in the design, collection and analysis of data and writing of the article. M.W. PORTUGUEZ collaborated part of the design, drafting and revising it.

\section{References}

Almeida, E. A., Madeira, G. D., Arantes, P. M. M., \& Alencar, M. A. (2010). Comparação da qualidade de vida entre idosos que participam e idosos que não participam de grupos de convivência na cidade de Itabira-MG. Revista Brasileira de Geriatria e Gerontologia, 13(3), 435-443.

Andrade, T. P., Mendonça, B. P. C. K., Lima, D. C., Alfenas, I. C., \& Bonolo, P. F. (2012). Projeto conviver: estímulo à convivência entre idosos do Catete, Ouro Preto, MG. Revista Brasileira de Educação Médica, 36(Supl.1), 81-85.

Andrade, A. N., Nascimento, M. M. P., Oliveira, M. M. D., Queiroga, R. M., Fonseca, F. L. A., Lacerda, S. N. B., \& Adami, F. (2014). Percepção de idosos sobre grupo de convivência: estudo na cidade de Cajazeiras-PB. Revista Brasileira de Geriatria e Gerontologia, 17(1), 39-48.

Antunes, H. K. M., Stella, S. G., Santos, R. F., Bueno, O. F. A., \& Mello, M. T. (2005). Depression, anxiety and quality of life scores in seniors after an endurance exercise program. Revista Brasileira de Psiquiatria, 27(4), 266-271.

Argimon, I. I. L., Stein, L. M., Xavier, F. M. F., \& Trentini, C. M. (2004). O impacto de atividades de lazer no desenvolvimento cognitivo de idosos. Revista Brasileira de Ciências do Envelhecimento Humano, 1(1), 38-47.

Batistoni, S. S. T., Neri, A. L., \& Cupertino, A. P. F. B. (2010). Medidas prospectivas de sintomas depressivos entre idosos residentes na comunidade. Revista de Saúde Pública, 44(6), 1137-1143.

Beckert, M., Irigaray, T. Q., \& Trentini, C. M. (2012). Qualidade de vida, cognição e desempenho nas funções executivas de idosos. Estudos de Psicologia (Campinas), 29(2), 155-162.

Benedetti, T. R. B., Borges, L. J., Petroski, E. L., \& Gonçalves, L. H. T. (2008). Atividade física e estado de 
saúde mental de idosos. Revista de Saúde Pública, 42(2), 302-307.

Benedetti, T. R. B., Mazo, G. Z., \& Borges, L. J. (2012). Condições de saúde e nível de atividade física em idosos participantes e não participantes de grupos de convivência de Florianópolis. Ciência \& Saúde Coletiva, 17(8), 2087-2093.

Braga, S. F. M., Peixoto, S. V., Gomes, I. C., Acúrcio, F. A., Andrade, E. L. G., \& Cherchiglia, M. L. (2011). Fatores associados com a qualidade de vida relacionada à saúde de idosos em hemodiálise. Revista de Saúde Pública, 45(6), 1127-1136.

Brigola, A. G., Manzini, C. S. S., Oliveira, G. B. S., Ottaviani, A. C., Sako, M. P., \& Vale, F. A. C. (2015). Subjective memory complaints associated with depression and cognitive impairment in the elderly: A systematic review. Dementia \& Neuropsychologia, 9(1), 51-57.

Carvalho, V. A., \& Caramelli, P. (2007). Brazilian adaptation of the Addenbrooke's Cognitive Examination-Revised (ACE-R). Dementia \& Neuropsychologia, 1(2), 212-216.

Chaves, E. C. L., Paulino, C. F., Souza, V. H. S., Mesquita, A. C., Carvalho, F. S., \& Nogueira, D. A. (2014). Qualidade de vida, sintomas depressivos e religiosidade em idosos: um estudo transversal. Texto \& Contexto - Enfermagem, 23(3), 648-655.

Cunha, J. A. (2001). Manual da versão em português das Escalas Beck. São Paulo: Casa do Psicólogo.

Erbolato, R. M. P. L. (2004). Suportes sociais na velhice: uma investigação preliminar. In Anais do XIV Congresso Brasileiro de Geriatria e Gerontologia e III Encontro Nacional das Ligas de Geriatria e Gerontologia, GERON, Salvador, BA.

Fleck, M. P. A., Louzada, S., Xavier, M., Chachamovich, E., Vieira, G., Santos, L., \& Pinzon, V. (2000). Aplicação da versão em português do instrumento abreviado de avaliação de qualidade de vida WHOQOL-BREF. Revista de Saúde Pública, 34(2), 178-183.

Freitas, M. A. V., \& Scheicher, M. E. (2010). Qualidade de vida de idosos institucionalizados. Revista Brasileira de Geriatria e Gerontologia, 13(3), 395-401.

Galhardo, V. A. C., Mariosa, M. A. S., \& Takata, J. P. I. (2010). Depressão e perfis sociodemográfico e clínico de idosos institucionalizados sem déficit cognitivo. Revista Médica de Minas Gerais, 20(1), 16-21.

García-Pena, C., Wagner, F. A., Sánchez-Garcia, S., JuárezCedillo, T., Espinel-Bermúdez, C., García-Gonzalez, J. J., ... Gallo, J. J. (2008). Depressive symptoms among older adults in Mexico City. Journal of General Internal Medicine, 23(12), 1973-1980.

Guedes, D. V., Barbosa, A. J. G., \& Magalhães, N. C. (2013). Qualidade de vida de idosos com declínio cognitivo: auto e heterorrelatos. Avaliação Psicológica, 12(1), 9-17.
Hamdan, A. C., \& Corrêa, P. H. (2009). Memória episódica e funções executivas em idosos com sintomas depressivos. Psico, 40(1), 73-80.

Hoffmann, E. J., Ribeiro, F. F., Farnese, J. M., \& Lima, E. W. B. (2010). Sintomas depressivos e fatores associados entre idosos residentes em uma comunidade no norte de Minas Gerais, Brasil. Jornal Brasileiro de Psiquiatria, 59(3), 190-197.

Hultsch, D. F., Hertzog, C., Small, B. J., \& Dixon, R. A. (1999). Use it or lose it: Engaged lifestyle as a buffer of cognitive decline in aging? Psychology and Aging, 14(2), 245-263.

Koch, R. F., Leite, M. T., Hildebrandt, L. M., Linck, C. L., Terra, M. G., \& Gonçalves, L. T. H. (2013). Depressão na percepção de idosas de grupos de convivência. Revista de Enfermagem da Universidade Federal de Pernambuco, 7(9), 5574-5582.

Leite, M. T., Hildebrandt, L. M., Kirchner, R. M., Winck, M. T., Silva, L. A. A., \& Franco, G. P. (2012a). Estado cognitivo e condições de saúde de idosos que participam de grupos de convivência. Revista Gaúcha de Enfermagem, 33(4), 64-71.

Leite, M. T., Winck, M. T., Hildebrandt, L. M., Kirchner, R. M., \& Silva, L. A. A. (2012b). Qualidade de vida e nível cognitivo de pessoas idosas participantes de grupos de convivência. Revista Brasileira de Geriatria e Gerontologia, 15(3), 481-492.

Lima, M. T. R., Silva, R. S., \& Ramos, L. R. (2009). Fatores associados à sintomatologia depressiva numa coorte urbana de idosos. Jornal Brasileiro de Psiquiatria, 58(1), $1-7$.

Lopes, R. M. F., Nascimento, R. F. L., Esteves, C. S., Terroso, L. B., \& Argimon, I. L. (2013). Funções executivas de idosos com depressão: um estudo comparativo. Cuadernos de Neuropsicología, 7(2), 72-86.

Minghelli, B., Tomé, B., Nunes, C., Neves, A., \& Simões, C. (2013). Comparação dos níveis de ansiedade e depressão entre idosos ativos e sedentários. Revista Psiquiatria Clínica, 40(2), 71-76.

Oliveira, E. R. A., Gomes, M. J., \& Paiva, K. M. (2011). Institucionalização e qualidade de vida de idosos da região metropolitana de Vitória - ES. Escola Anna Nery, 15(3), 518-523.

Paulo, D. L. V., \& Yassuda, M. S. (2010). Queixas de memória de idosos e sua relação com escolaridade, desempenho cognitivo e sintomas de depressão e ansiedade. Archives of Clinical Psychiatry, 37(1), 23-26.

Rangel, E. S. S., Belasco, A. G. S., \& Diccini, S. (2013). Qualidade de vida de pacientes com acidente vascular cerebral em reabilitação. Acta Paulista de Enfermagem, 26(2), 205-212.

Rocha, J. P., Klein, O. J., \& Pasqualotti, A. (2014). Qualidade de vida, depressão e cognição a partir da educação gerontológica mediada por uma rádio-poste em instituições de longa permanência para idosos. 
Revista Brasileira de Geriatria e Gerontologia, 17(1), 115-128.

Scoralick, F. M., Pinheiro, J. E. S., Silva, S. A., \& Cunha, U. G. V. (2011). Depressão e demência/diagnóstico diferencial. In E. V. Freitas \& L. Py (Orgs.), Tratado de geriatria e gerontologia (pp.251-255). Rio de Janeiro: Guanabara Koogan

Serbim, A. K., \& Figueiredo, A. E. P. L. (2011). Qualidade de vida de idosos em um grupo de convivência. Scientia Médica, 21(4), 166-172.

Silva, H. O., Carvalho, M. J. A. D., Lima, F. E. L., \& Rodrigues, L. V. (2011). Perfil epidemiológico de idosos frequentadores de grupos de convivência no município de Iguatu, Ceará. Revista Brasileira de Geriatria e Gerontologia, 14(1), 123-133.

Silva, L. S. V., Silva, T. B. L., Falcão, D. V. S., Batistoni, S. S. T., Lopes, A., Cachioni, M., Neri, A. L., \& Yassuda, M. S. (2014). Relations between memory complaints, depressive symptoms and cognitive performance among community dwelling elderly. Archives of Clinical Psychiatry, 41(3), 67-71.

Silveira, M. M. (2012). Envelhecimento e usuários de informática: repercussões de um programa ergonômico (Dissertação de mestrado não-publicada). Universidade de Passo Fundo, Rio Grande do Sul.

Steibel, M. N., \& Almeida, R. M. M. (2010). Estudo de caso - avaliação neuropsicológica: depressão x demência. Aletheia, 31, 111-120.

Takemoto, A. Y., Okubo, P., Bedendo, J., \& Carreira, L. (2011). Avaliação da qualidade de vida em idosos submetidos ao tratamento hemodialítico. Revista Gaúcha de Enfermagem, 32(2), 256-262.
Tavares, D. M. S., \& Dias, F. A. (2012). Capacidade funcional, morbidades e qualidade de vida de idosos. Texto \& Contexto - Enfermagem, 21(1), 112-120.

Vitorino, L. M., Paskulin, L. M. G., \& Vianna, L. A. C. (2013). Qualidade de vida de idosos da comunidade e de instituições de longa permanência: estudo comparativo. Revista Latino-Americana de Enfermagem, 21(Esp.), 3-11.

Winocur, G., Palmer, H., Dawson, D., Binns, M., Bridges, K., \& Stuss, D. (2007). Cognitive rehabilitation in the elderly: An evaluation of psychosocial factors. Journal of the International Neuropsychological Society, 13(1), 153-165.

World Health Organization. (1995). The World Health Organization Quality of Life assessment (WHOQOL): Position paper from the World Health Organization. Social Science \& Medicine, 41(10), 1403-1409.

Yassuda, M. S., \& Silva, H. S. (2010). Participação em programas para a terceira idade: impacto sobre a cognição, humor e satisfação com a vida. Estudos de Psicologia (Campinas), 27(2), 207-214.

Yen, Y. C., Rebok, G. W., Gallo, J. J., Jones, R. N., \& Tennstedt, S. L. (2011). Depressive symptoms impair everyday problem-solving ability through cognitive abilities in late life. American Journal of Geriatric Psychiatry, 19(2), 142-150.

Yesavage, J. A., Brink, T. L., Rose, T. L., Lum, O., Huang, V., Adey, M., \& Leirer, V. O. (1983). Development and validation of a geriatric depression screening scale: $A$ preliminary report. Journal of Psychiatric Research, 17(1), 37-49.

Received: July 8, 2015

Final version: November 17, 2015

Approved: January 13, 2016 